Provided for non-commercial research and education use. Not for reproduction, distribution or commercial use.

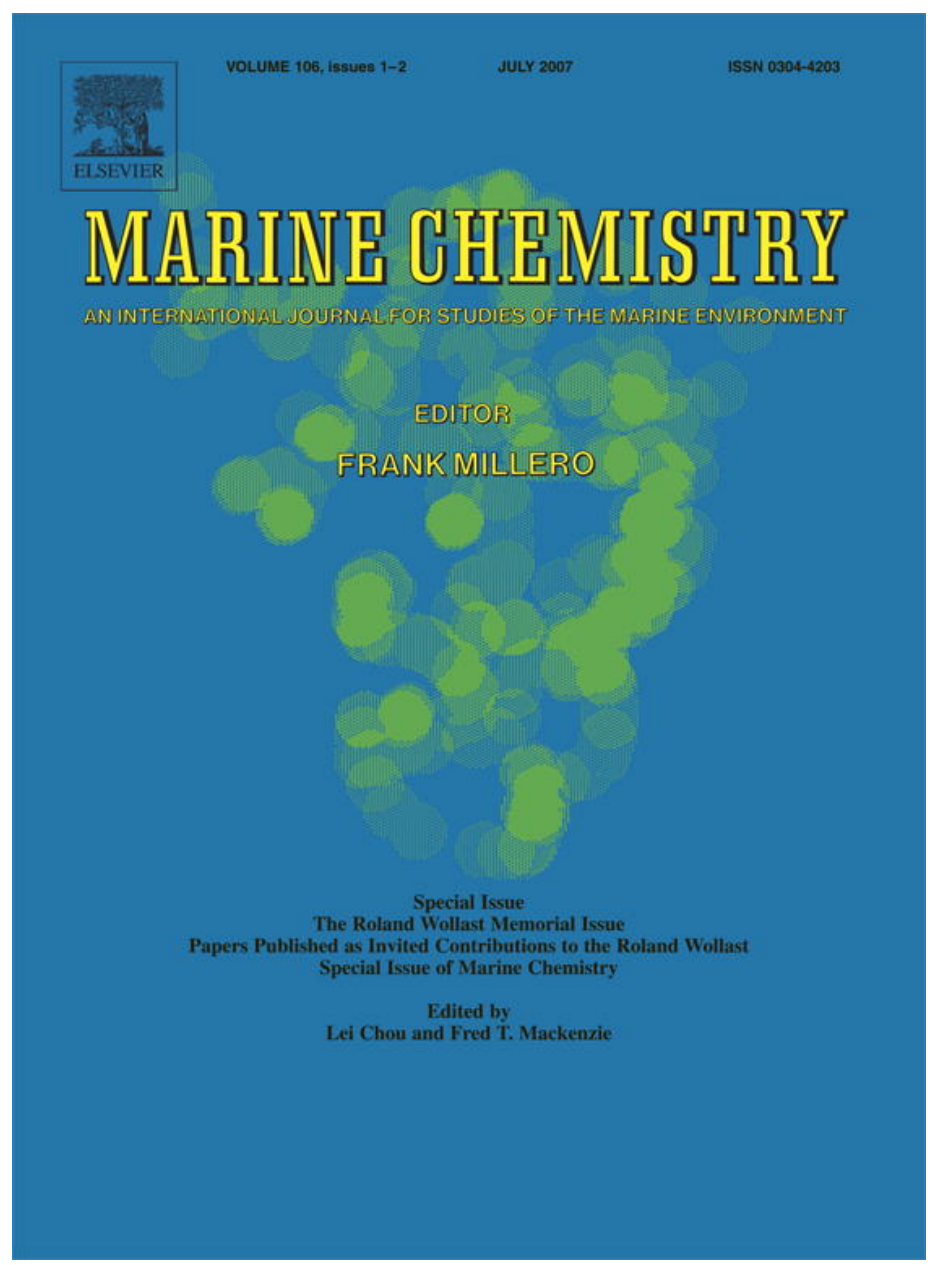

This article was published in an Elsevier journal. The attached copy

is furnished to the author for non-commercial research and education use, including for instruction at the author's institution, sharing with colleagues and providing to institution administration.

Other uses, including reproduction and distribution, or selling or licensing copies, or posting to personal, institutional or third party websites are prohibited.

In most cases authors are permitted to post their version of the article (e.g. in Word or Tex form) to their personal website or institutional repository. Authors requiring further information regarding Elsevier's archiving and manuscript policies are encouraged to visit:

http://www.elsevier.com/copyright 


\title{
High temporal coverage of carbon dioxide measurements in the Southern Bight of the North Sea
}

\author{
L.-S. Schiettecatte ${ }^{a, *}$, H. Thomas ${ }^{b}$, Y. Bozec ${ }^{c}$, A.V. Borges ${ }^{a}$ \\ ${ }^{a}$ Université de Liège, Interfacultary Centre for Marine Research, Chemical Oceanography Unit, 4000 Liège, Belgium \\ ${ }^{\mathrm{b}}$ Canada Research Chair, Dalhousie University, Department of Oceanography, Halifax, NS, Canada B3H4J1 \\ c Scripps Institution of Oceanography, Geophysical Research Division, San Diego, CA, USA
}

Received 7 February 2006; received in revised form 21 December 2006; accepted 10 January 2007

Available online 21 January 2007

\begin{abstract}
A monthly survey of the partial pressure of $\mathrm{CO}_{2}\left(\mathrm{pCO}_{2}\right)$ was carried in the Southern Bight of the North Sea (SBNS) from June 2003 to May 2004. The spatial variability of the surface distribution of the $\mathrm{pCO}_{2}$ was relatively small (within a range of $10-70 \mu \mathrm{atm})$ compared to the amplitude in the seasonal signal ( $260 \mu \mathrm{atm})$. On an annual scale, the pCO $\mathrm{P}_{2}$ dynamics appeared to be controlled by biological processes (primary production in springtime and respiratory processes in summer), rather than temperature (in summer). The comparison with measurements carried out in 2001 and 2002 (13 cruises) shows that the inter-annual variability of $\mathrm{pCO}_{2}$ was close to the range of the spatial variability and mostly observed in spring, associated to biological processes (primary production). Net ecosystem production estimated from dissolved inorganic carbon (DIC) temporal variations showed that the SBNS is autotrophic, at an annual rate of $6.3 \mathrm{~mol} \mathrm{C} \mathrm{m}^{-2} \mathrm{yr}^{-1}$. The decoupling in time between autotrophy in spring and heterotrophy in summer, associated to the relatively rapid flushing time of the water mass in the area ( $\sim 70$ days), might allow the export of a fraction of the springtime synthesized organic matter to the adjacent areas of the North Sea. The SBNS was on a yearly basis a sink of atmospheric $\mathrm{CO}_{2}$ at a rate of $-0.7 \mathrm{~mol} \mathrm{C} \mathrm{m} \mathrm{yr}^{-1}$.
\end{abstract}

(C) 2007 Elsevier B.V. All rights reserved.

Keywords: North Sea; Scheldt estuary; Air-sea $\mathrm{CO}_{2}$ fluxes; Dissolved inorganic carbon; Net ecosystem production; Biological pump

\section{Introduction}

The representation of the present-day $\mathrm{CO}_{2}$ fluxes and the understanding of their biogeochemical drivers are essential requirements to reliably validate numerical models, as well as to strengthen their predictive capabilities on future increase of atmospheric $\mathrm{CO}_{2}$. It is well established that open oceanic waters are a major sink for anthropogenic $\mathrm{CO}_{2}$, absorbing about $48 \%$ of the $\mathrm{CO}_{2}$

\footnotetext{
* Corresponding author. Tel.: +32 436633 26; fax: +3243669729.

E-mail address: laure-sophie.schiettecatte@ulg.ac.be (L.-S. Schiettecatte).
}

emissions related fossil fuels burning and cement production (Sabine et al., 2004). However, coastal ecosystems remain grossly under-represented in global present-day $\mathrm{CO}_{2}$ budgets. Estimates of the global $\mathrm{CO}_{2}$ sink over marginal seas based on scaled $\mathrm{CO}_{2}$ fluxes $\left(F_{\mathrm{CO}_{2}}\right)$ computed from field measurements of the partial pressure of $\mathrm{CO}_{2}\left(\mathrm{pCO}_{2}\right)$ or from carbon mass balances range between -0.2 and $-1.0 \mathrm{PgC} \mathrm{yr}^{-1}$ (Tsunogai et al., 1999; Chen, 2004; Thomas et al., 2004; Borges, 2005; Borges et al., 2005). This wide range of estimates reflects to some extent the latitudinal and ecosystem variability of coastal environments, but also to a large extent the insufficient data coverage in these heterogeneous and 
dynamic environments. Nevertheless, such values are comparable to the open ocean sink of atmospheric $\mathrm{CO}_{2}$ estimated to $-1.6 \mathrm{PgC} \mathrm{yr}^{-1}$ (Takahashi et al., 2002).

The Southern Bight of the North Sea (SBNS from the Dover Strait to $53^{\circ} \mathrm{N}$, Fig. 1) is a permanently wellmixed coastal zone that receives high inputs of nutrients and organic and inorganic carbon from the Scheldt, Rhine/Meuse and Thames estuaries, and indirectly from the Seine through inputs from the English Channel. Previous studies in the SBNS reported measurements of $\mathrm{pCO}_{2}$ along transects or survey approaches at seasonal or annual scales (Kempe and Pegler, 1991; Hoppema, 1991; Bakker et al., 1996; Frankignoulle and Borges, 2001; Borges and Frankignoulle, 2003; Thomas et al., 2004). These studies based on different temporal and spatial coverages of $\mathrm{pCO}_{2}$ in surface waters of the SBNS report a broad range of $\mathrm{pCO}_{2}$ and $F_{\mathrm{CO}_{2}}$ values. Indeed, in dynamic and heterogeneous coastal ecosystems, the two sampling approaches (high spatial coverage with low temporal resolution versus high temporal resolution at a fixed station) can lead to uncertainties regarding the $\mathrm{pCO}_{2}$ dynamics and the direction and amplitude of $\mathrm{F}_{\mathrm{CO}_{2}}$ (e.g. Schiettecatte et al., 2006).

In the present study, the spatial distribution and temporal variability of surface water $\mathrm{pCO}_{2}$ in the SBNS are investigated based on 23 cruises from 2001 to 2004, with a monthly dataset from June 2003 to May 2004. We

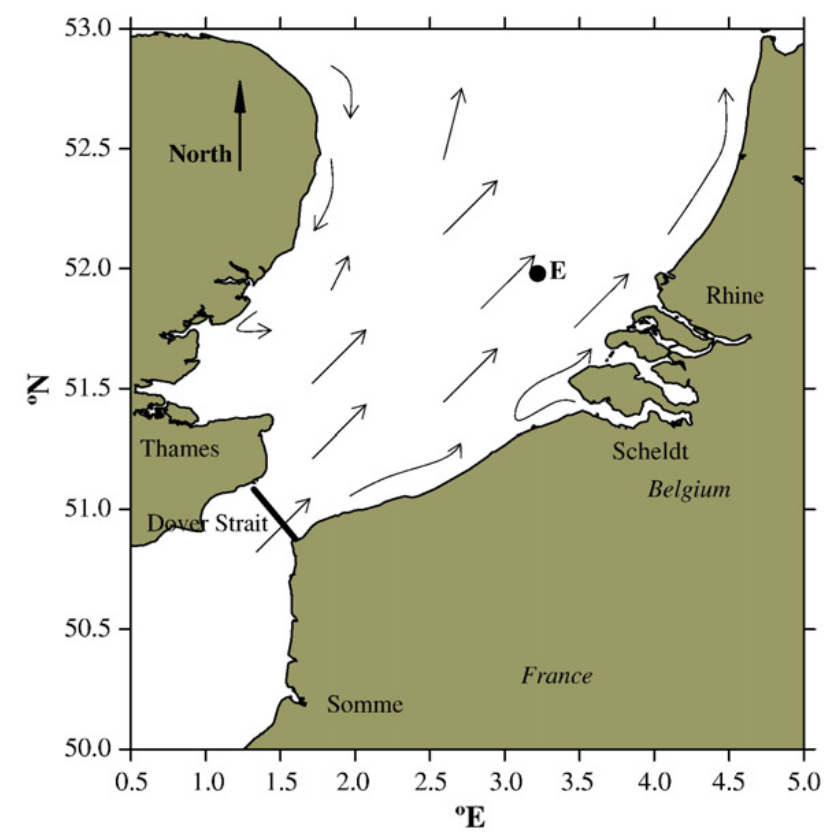

Fig. 1. Map of the studied area. Arrows represent general pattern of surface currents within the area. Black line shows the limit of the English Channel. The filled circle shows the location of the wind speed station (Europlatform, E) used for the computation of air-sea $\mathrm{CO}_{2}$ fluxes. attempt to address the biogeochemical drivers of the seasonal $\mathrm{pCO}_{2}$ dynamics and some of the factors involved in the inter-annual $\mathrm{pCO}_{2}$ variability. Net ecosystem production (NEP) is estimated from the temporal variation of dissolved inorganic carbon (DIC), and $F_{\mathrm{CO}_{2}}$. The latter estimates allow us to characterize the SBNS as a source or a sink for atmospheric $\mathrm{CO}_{2}$.

\section{Materials and methods}

Data were obtained from 2001 to 2004 from 23 cruises on board of the R.V. Belgica. The ship tracks are shown in Figs. 2 and 3. Cruises always started from Zeebrugge harbour, close to the mouth of the Scheldt estuary $\left(3.18^{\circ} \mathrm{E} 51.3^{\circ} \mathrm{N}\right)$, and data were collected to a longitude of $0.5^{\circ} \mathrm{E}$ and to latitude of $53^{\circ} \mathrm{N}$, when possible (Fig. 1). Underway parameters (salinity, temperature and $\mathrm{pCO}_{2}$ ) were sampled with a 1 min frequency from the surface seawater supply of the ship (pump inlet at a depth of $2.5 \mathrm{~m}$ ). Salinity and temperature were measured using a SeaBird ${ }^{\circledR}$ SBE21 thermosalinograph. $\mathrm{pCO}_{2}$ was measured by means of a non-dispersive infrared gas analyzer (IRGA, Li-Cor ${ }^{\circledR}, \mathrm{Li}-6262$ ) and an equilibrator (Frankignoulle et al., 2001). For further details on the equilibrator design and performance tests, refer to Frankignoulle et al. (2001). The IRGA was calibrated weekly using pure nitrogen (Air Liquide Belgium) and two gas mixtures of a $\mathrm{CO}_{2}$ molar fraction of 366 and 810 ppm (Air Liquide Belgium), calibrated against two National Oceanic and Atmospheric Administration (NOAA) standards with a $\mathrm{CO}_{2}$ molar fraction of 361 and $774 \mathrm{ppm}$. The temperature at the outlet of the equilibrator was monitored with a platinum resistance thermometer (PT100, METROHM $\left.{ }^{\circledR}\right)$, with an estimated accuracy of $\pm 0.05{ }^{\circ} \mathrm{C}$. The $\mathrm{pCO}_{2}$ values were corrected for the temperature difference between in-situ seawater and water in the equilibrator using the algorithm proposed by Copin-Montégut $(1988,1989)$ and then corrected to the local barometric pressure. The accuracy of the $\mathrm{pCO}_{2}$ measurement by equilibration was estimated to $\pm 2 \mu \mathrm{atm}$ (cumulated errors on temperature correction and instrument calibration). Oxygen $\left(\mathrm{O}_{2}\right)$ concentrations were measured in 2003 with a 1 min frequency using a galvanic electrode calibrated daily against discrete samples, and every $30 \mathrm{~min}$ by discrete sampling in 2004. In parallel of $\mathrm{O}_{2}$ sampling, total alkalinity (TA) discrete surface samples were also taken. $\mathrm{O}_{2}$ and TA were measured using respectively the Winkler method and the Gran electrotitration method. The accuracy of TA measurements was $\pm 3 \mu \mathrm{mol} \mathrm{kg}{ }^{-1}$. The oxygen saturation level $\left(\mathrm{oO}_{2}\right)$ was computed from the observed concentration of dissolved $\mathrm{O}_{2}$ and the concentration of 

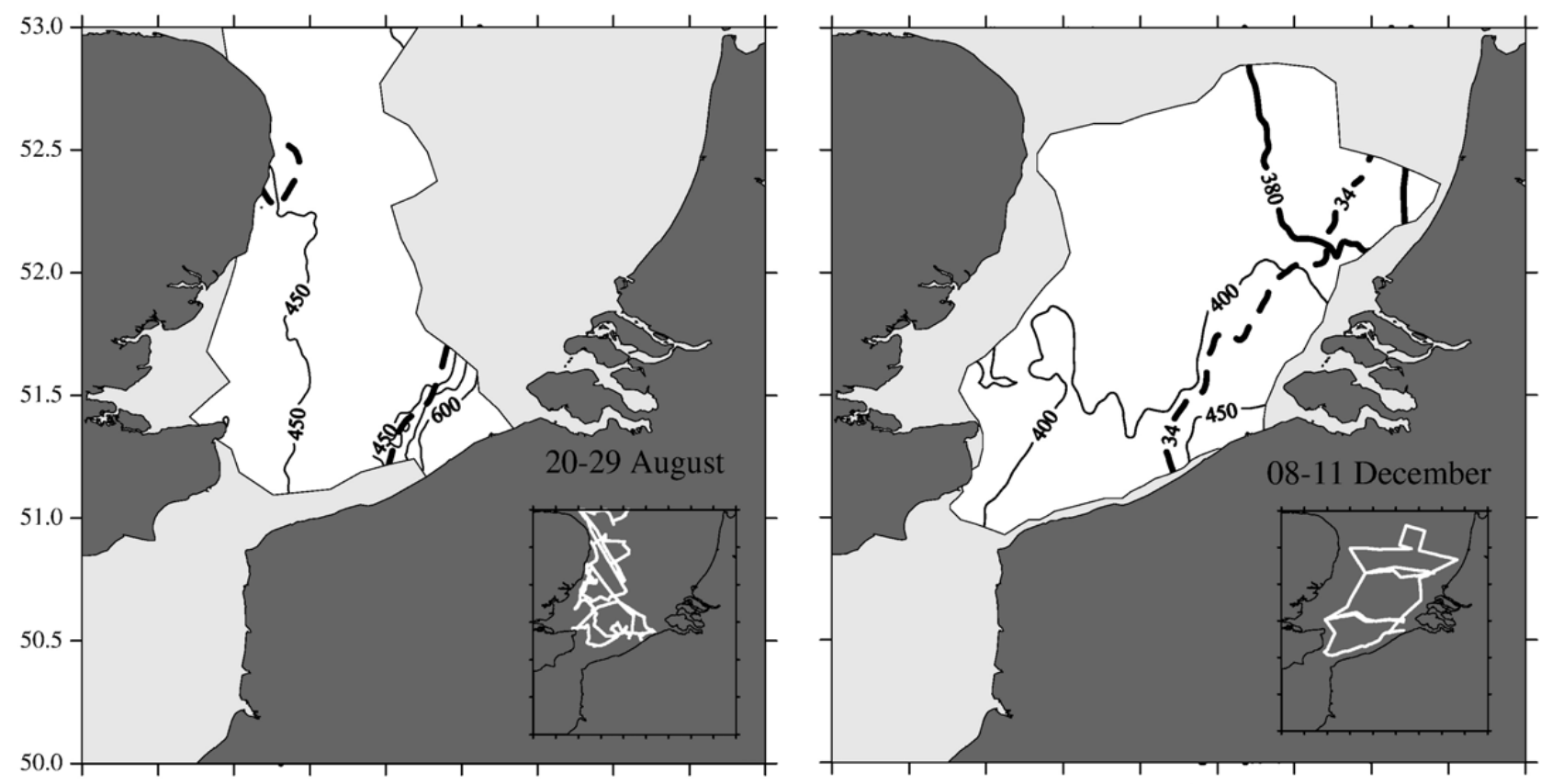

${ }^{\circ} \mathbf{E}$
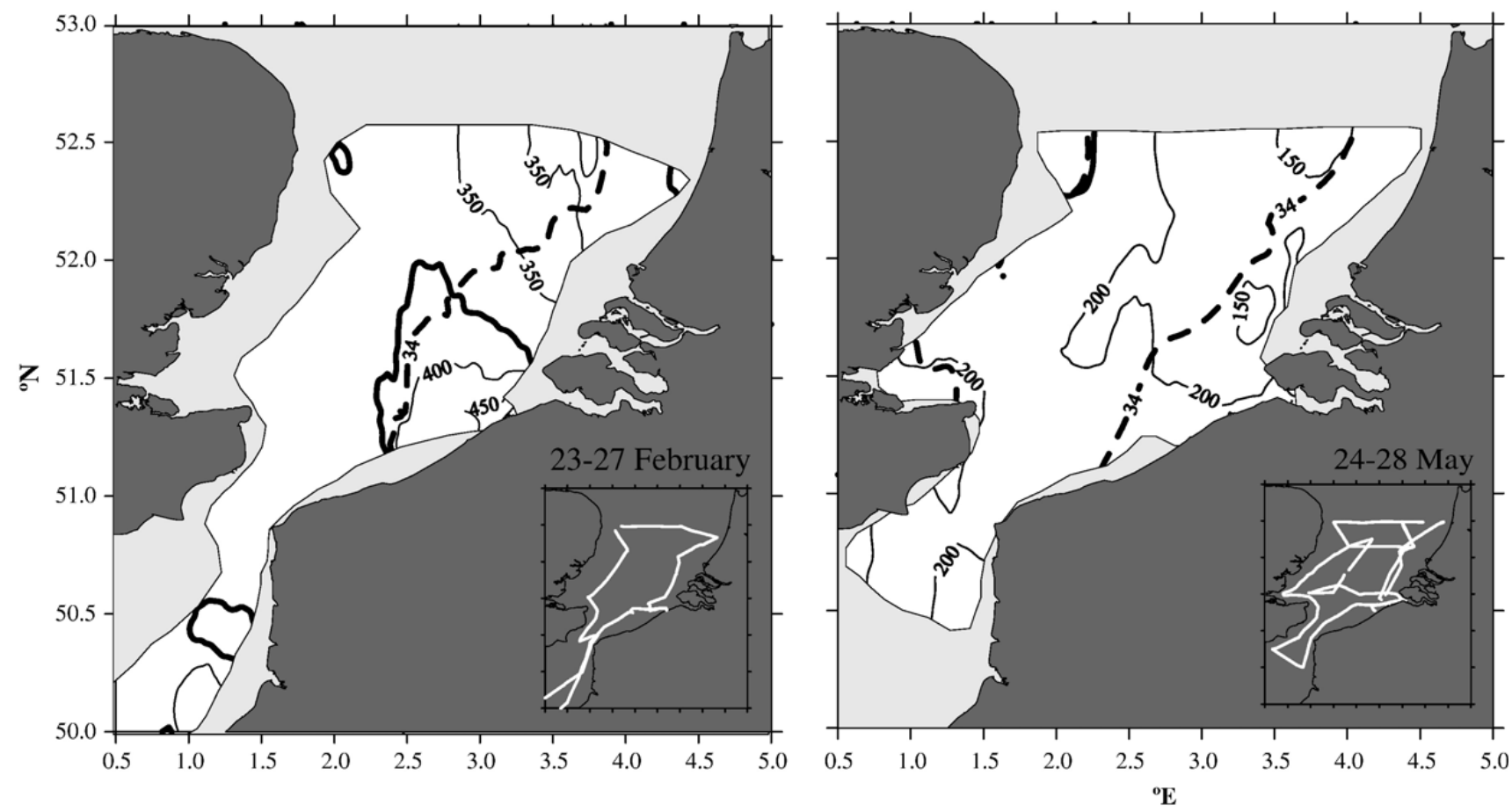

Fig. 2. Surface distribution of the partial pressure of $\mathrm{CO}_{2}\left(\mathrm{pCO}_{2}\right)$ in the Southern Bight of the North Sea (SBNS) and adjacent areas (English Channel) in August and December 2003, and in February and May 2004. The black line shows the limit of estuarine plumes defined by the 34 isohaline. The black bold line shows the atmospheric equilibrium. Inserts show the ship tracks.

$\mathrm{O}_{2}$ at saturation calculated according to Benson and Krause (1984). The accuracy of $\mathrm{O}_{2}$ measurements was $\pm 0.5 \mu \mathrm{mol} \mathrm{kg}^{-1}(0.2 \%$ of level of saturation). DIC was computed from $\mathrm{pCO}_{2}$ and TA measurements using carbonic acid constants given by Roy et al. (1993), dissociation constants of boric acid given by Dickson (1990) and the $\mathrm{CO}_{2}$ solubility coefficient $(\alpha)$ given by Weiss (1974). The accuracy of DIC computed from TA and $\mathrm{pCO}_{2}$ were estimated to be $\pm 5 \mu \mathrm{mol} \mathrm{kg}^{-1}$ (cumulated errors on TA and $\mathrm{pCO}_{2}$ ).

$F_{\mathrm{CO}_{2}}$ was computed from the $\mathrm{pCO}_{2}$ air-sea gradient $\left(\Delta \mathrm{pCO}_{2}=\mathrm{pCO}_{2}-\mathrm{pCO}_{2 \mathrm{~atm}}\right.$, where $\mathrm{pCO}_{2 \text { atm }}$ refers to values in the atmosphere), $\alpha$, and the gas transfer velocity $(k)$ according to:

$F_{\mathrm{CO}_{2}}=\alpha k \Delta p \mathrm{CO}_{2}$ 
We used nominally the $k$ parameterization as function of wind speed given by Nightingale et al. (2000), established in the North Sea. For comparative purposes with previous studies, computations were also carried out with the $k$ parameterizations as function of wind speed given by Wanninkhof (1992), and Wanninkhof and McGillis (1999). We used the wind speed $\left(u_{10}\right)$ data measured at the meteorological station Europlatform $\left(3^{\circ} 22 \mathrm{E} 51^{\circ} 98 \mathrm{~N}\right)$ provided by the Royal Netherlands Meteorological Institute (http://www.knmi.nl/samenw/hydra).
As the SBNS is bordered by industrialized countries, the atmospheric $\mathrm{CO}_{2}$ signal is expected to be increased by continental $\mathrm{CO}_{2}$ (e.g. Bakker et al., 1996; Borges and Frankignoulle, 2003). As there is no apparent trend in wind direction in this area (OSPARCOM, 2002) and as $\mathrm{pCO}_{2 \mathrm{~atm}}$ was not measured during the cruises, 2 stations located in the North Sea were chosen as (1) continentally influenced (Kollumerwaard, $6.17^{\circ} \mathrm{E} 53.20^{\circ} \mathrm{N}$, referred as $\mathrm{K}$ hereafter), and (2) free of continental $\mathrm{CO}_{2}$ contamination (Shetland station, $1.15^{\circ} \mathrm{W} 60.10^{\circ} \mathrm{N}$,
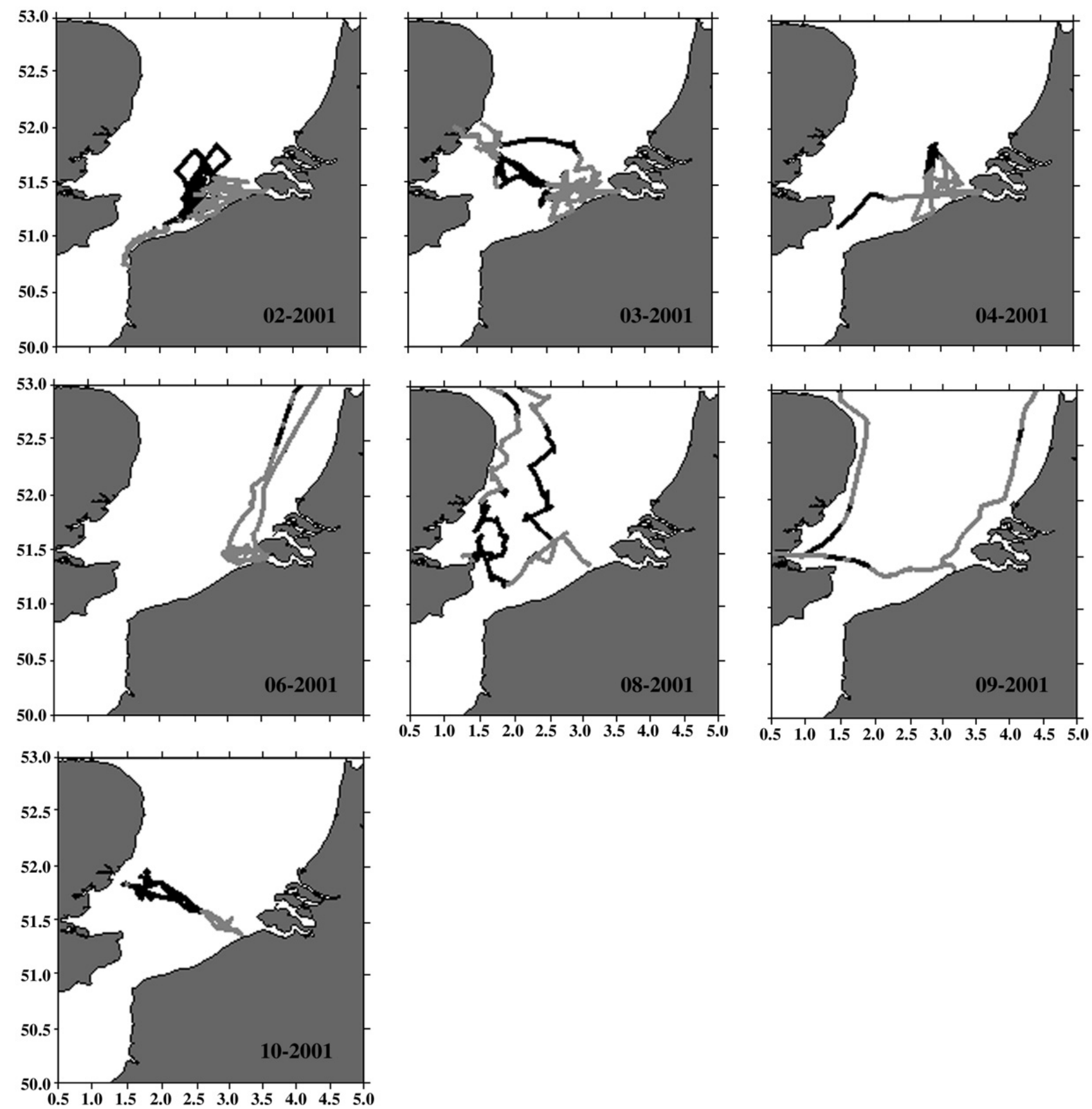

Fig. 3. Ship track for cruises from 2001 to 2002 (MM-YY). Grey tracks show surface area covered by the estuarine plumes. Left axis: Latitude (50 to $\left.53^{\circ} \mathrm{N}\right)$, right axis $\left(0.5\right.$ to $\left.5^{\circ} \mathrm{E}\right)$. 

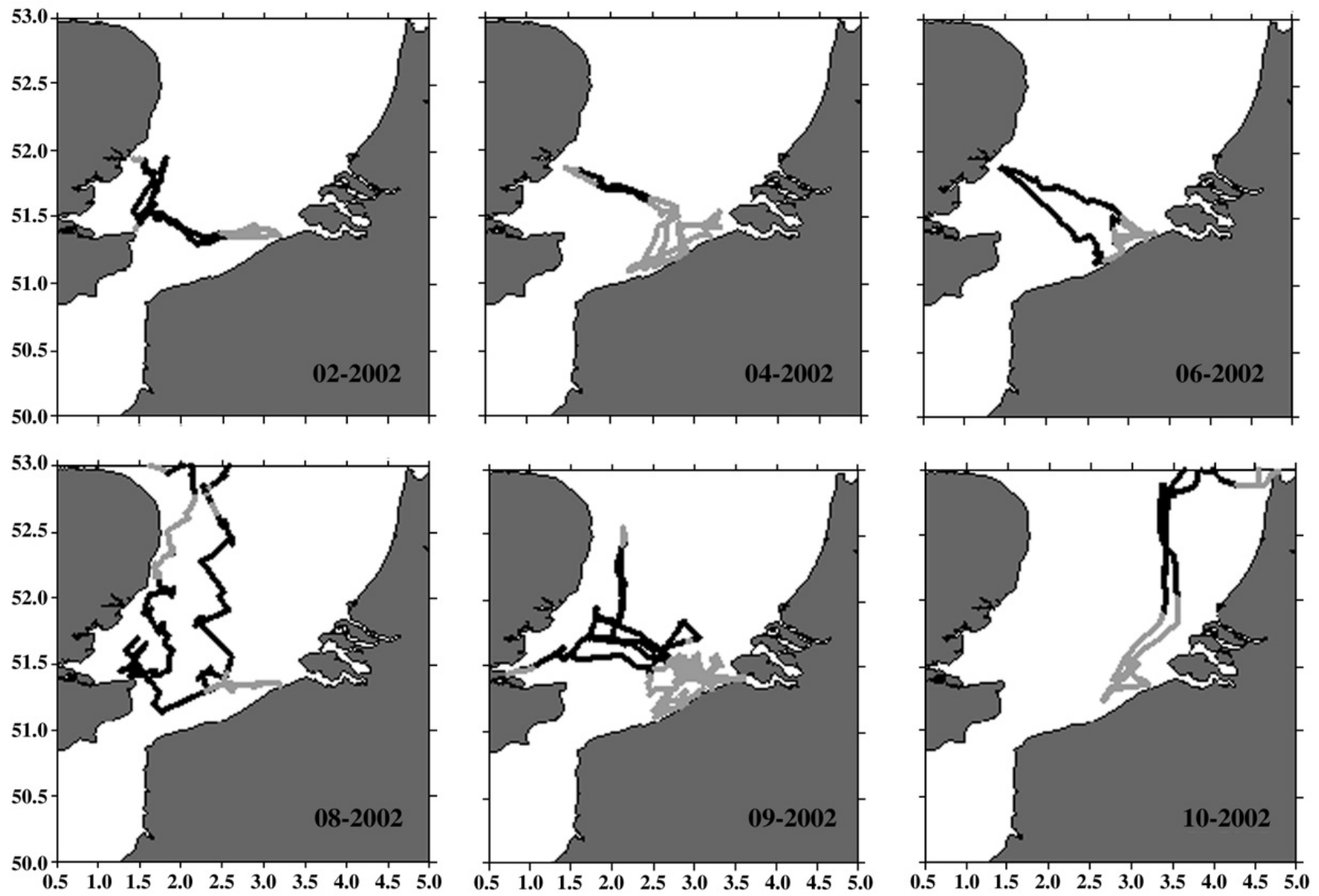

Fig. 3 (continued).

referred as $\mathrm{S}$ hereafter). Data from $\mathrm{K}$ were provided by the Dutch National Air Quality Monitoring Network supplied by the National Institute of Public Health and Environment and data from $\mathrm{S}$ were provided by the GLOBALVIEW- $\mathrm{CO}_{2}$ (2006) (ftp.cmdl.noaa.gov, Path: $\mathrm{ccg} / \mathrm{co} 2 /$ GLOBALVIEW). Monthly $\mathrm{pCO}_{2 \mathrm{~atm}}$ (in dry air) were compared with $\mathrm{pCO}_{2 \mathrm{~atm}}$ measurements obtained in the SBNS during 4 cruises in 2001 and 2002 (September and November 2001, March and May 2002) during a carbon and nutrient cycling study in the same area of the North Sea (Thomas et al., 2004) (Table 1). As the measurements of $\mathrm{pCO}_{2 \mathrm{~atm}}$ from the latter study were in between those from $\mathrm{K}$ and $\mathrm{S}$ (Table 1), monthly means of $\mathrm{pCO}_{2 \mathrm{~atm}}$ from the 2 stations were used to compute $\Delta \mathrm{pCO}_{2}$. Values of $\mathrm{pCO}_{2 \mathrm{~atm}}$ in dry air were converted into $\mathrm{pCO}_{2 \mathrm{~atm}}$ in wet air according to Dickson and Goyet (1994).

The net ecosystem production (NEP, in $\mathrm{mmol} \mathrm{C} \mathrm{m}{ }^{-2}$ day $^{-1}$ ) was computed from the temporal DIC variations from August 2003 to May 2004, according to the following equation:

$\mathrm{NEP}=\frac{\left(\mathrm{DIC}_{1}-\mathrm{DIC}_{2}\right) \times d}{\Delta t}-F_{\mathrm{CO}_{2}}$ where $\mathrm{DIC}_{1}$ and $\mathrm{DIC}_{2}$ are the mean values in $\mathrm{mmol} \mathrm{m}^{-3}$ during two consecutive cruises, $F_{\mathrm{CO}_{2}}$ in $\mathrm{mmol} \mathrm{C} \mathrm{m}{ }^{-2}$ day $^{-1}$ is the mean $F_{\mathrm{CO}_{2}}$ for the two cruises, $\Delta t$ is the time interval in days between the two cruises, and $d$ is depth in $\mathrm{m}$. The computations were carried out using a mean depth of $30 \mathrm{~m}$ (based on measurements on board of the R.V. Belgica), and when $\Delta t$ did not exceed the average flushing time in the area of about 73 days (OSPARCOM, 2002).

This method is suitable for permanently well-mixed and shallow systems such as the SBNS since it does not require the determination of seasonally variable mixed layer depths and provides an integrated signal

Table 1

Monthly atmospheric $\mathrm{pCO}_{2}$ (in ppm, in dry air) for stations Kollumerwaard (K) and Shetland (S) in 2001 and 2002, and the mean $\mathrm{pCO}_{2 \mathrm{~atm}}$ measurements (in ppm, in dry air) from Thomas et al. (2004) in the Southern Bight of the North Sea

\begin{tabular}{lllll}
\hline Month & K & S & Mean K and S & Thomas et al. (2004) \\
\hline September 2001 & 373 & 363 & 368 & 364 \\
November 2001 & 381 & 373 & 377 & 383 \\
March 2002 & 392 & 378 & 385 & 383 \\
May 2002 & 395 & 378 & 386 & 383 \\
\hline
\end{tabular}


for the pelagic and benthic compartments. We assume that the DIC dynamics is only driven by air-sea $\mathrm{CO}_{2}$ exchange and production/degradation of organic matter. Calcium carbonate production/dissolution is assumed to be negligible based on the current knowledge of this area (Borges and Frankignoulle, 1999, 2002; Frankignoulle and Borges, 2001; Gypens et al., 2004; Schiettecatte et al., 2006). The major caveat of this method is that the advective inputs/outputs of DIC must be assumed to be constant during two cruises. This uncertainty can be assumed minimal as long as the time step (time interval between two cruises) is lower than the flushing time ( $\sim 73$ days, OSPARCOM, 2002).

\section{Results and discussion}

\subsection{Spatial distribution and seasonal cycle of $\mathrm{pCO}_{2}$}

Fig. 2 shows for the annual cycle 2003-2004 the seasonal variations of the spatial distribution of $\mathrm{pCO}_{2}$ in the surface waters of the SBNS and adjacent areas (eastern English Channel), while Fig. 4 show the monthly averages of $\mathrm{pCO}_{2}, \% \mathrm{O}_{2}$, TA and DIC for the SBNS excluding the eastern English Channel. For a given cruise, the $\mathrm{pCO}_{2}$ distribution in the SBNS was quite homogeneous, as the amplitude of spatial variations ranged between 10 and $70 \mu \mathrm{atm}$ (at most $50 \mu \mathrm{atm}$ when estuarine plumes are excluded, e.g. for the area with salinities $>34)$, which was relatively small compared to the amplitude of the seasonal signal $(\sim 260 \mu \mathrm{atm}$, Table 2). Maximum and minimum $\mathrm{pCO}_{2}$ values in the SBNS were observed in August and April 455 \pm 36 and $192 \pm 35 \mu \mathrm{atm}$, respectively, Table 2). Higher $\mathrm{pCO}_{2}$ values were observed along the Belgian coastal zone (BCZ e.g. eastern part of the SBNS including the Scheldt plume; up to $900 \mu \mathrm{atm}$ in August) related to the discharge of DIC rich waters from the heterotrophic inner Scheldt estuary (for details on the $\mathrm{pCO}_{2}$ dynamics in the BCZ refer to Borges and Frankignoulle, 1999, 2002; Schiettecatte et al., 2006). During winter, the SBNS was oversaturated in $\mathrm{CO}_{2}$ with respect to the atmosphere, when temperature $\left(\sim 6.3 \pm 0.3{ }^{\circ} \mathrm{C}\right.$ in February) and biological activities $\left(\mathrm{O}_{2}\right.$ close to atmospheric equilibrium, Fig. 4A) were at the lowest. According to the spatial distribution of $\% \mathrm{O}_{2}$ (data not shown) the onset of the diatom phytoplanktonic bloom was in March (Rousseau et al., 2002), outside of the Scheldt and Rhine/Meuse plumes, due to better light penetration outside the plumes (Van bennekom and Wetsteijn, 1990). The phytoplanktonic bloom then spread within 3 weeks to the entire studied region as shown by the
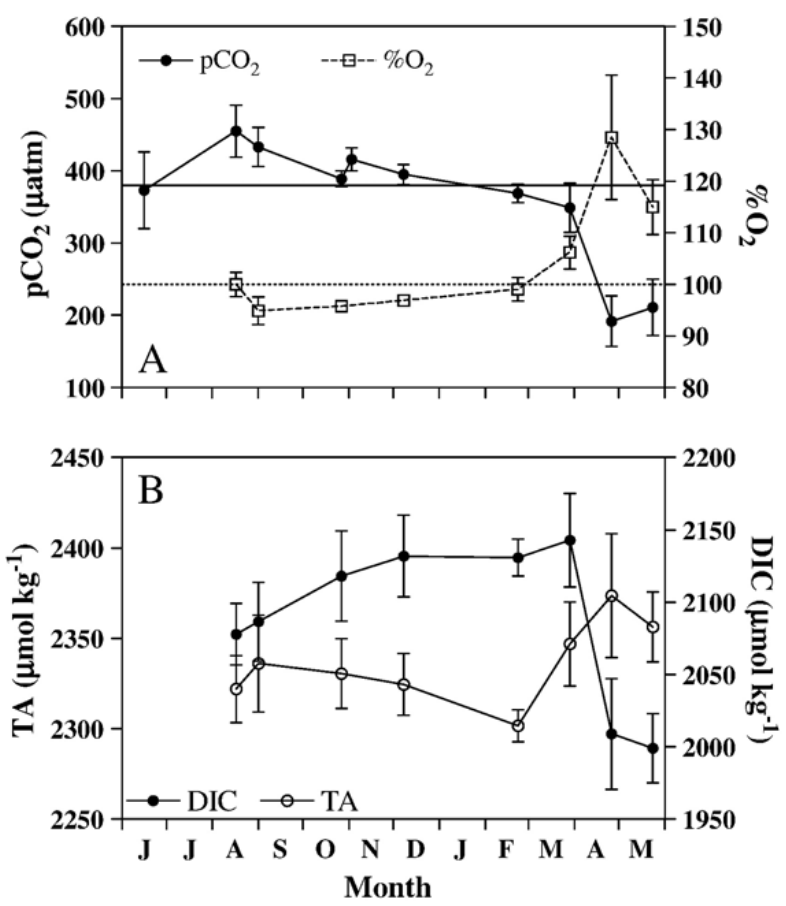

Fig. 4. Monthly averaged values for the Southern Bight of the North Sea (SBNS) from June 2003 to May 2004 of: (A) partial pressure of $\mathrm{CO}_{2}$ ( $\mathrm{pCO}_{2}$, in $\mu \mathrm{atm}$ filled circles) and percentage of oxygen saturation $\left(\% \mathrm{O}_{2}\right.$, empty squares) and (B) Total alkalinity (TA, empty circles) and dissolved inorganic carbon (DIC, filled circles) in $\mu \mathrm{mol}$ $\mathrm{kg}^{-1}$. Error bars represent standard errors of the means. Average atmospheric equilibrium of $\mathrm{pCO}_{2}$ and $\mathrm{O}_{2}$ are shown as solid and dotted lines, respectively.

strong $\mathrm{CO}_{2}$ undersaturation in April-May $\left(\mathrm{pCO}_{2}\right.$ $\sim 190 \mu \mathrm{atm}$; Figs. 2 and $4 \mathrm{~A})$ and high $\% \mathrm{O}_{2}(120 \%$ for the SBNS, and up to $180 \%$ for the Scheldt plume, data not shown). The $\mathrm{pCO}_{2}$ decrease in the SBNS was also mirrored by a DIC decrease between February and May of about $150 \mu \mathrm{mol} \mathrm{kg}-1$, whereas TA increased by about $70 \mu \mathrm{mol} \mathrm{kg}{ }^{-1}$ (Fig. 4B). The mean nitrate concentration within the BCZ from a 7 years survey (1993-2000) is about $31 \mu \mathrm{M}$ with maximum values of $140 \mu \mathrm{M}$ for salinities $<33$ and about $50 \mu \mathrm{M}$ for salinities $>33$ (De Galan et al., 2004). High nitrate concentrations were also reported in the BCZ by van Der Zee and Chou (2005) and Lancelot et al. (2005), respectively 80 and $50 \mu \mathrm{M}$. The TA increase should then be related to the assimilation of nitrate by phytoplankton as the uptake of 1 mole of nitrate causes an increase of 1 mole of TA (Brewer and Goldman, 1976).

During early summer (June 2003, data not shown), two contrasting patterns were observed: while the most of the SBNS remained $\mathrm{CO}_{2}$ undersaturated, the Scheldt plume was strongly $\mathrm{CO}_{2}$ oversaturated. Strong heterotrophic activities had already started in June 2003 in the Scheldt plume, unlike the rest of the SBNS. 


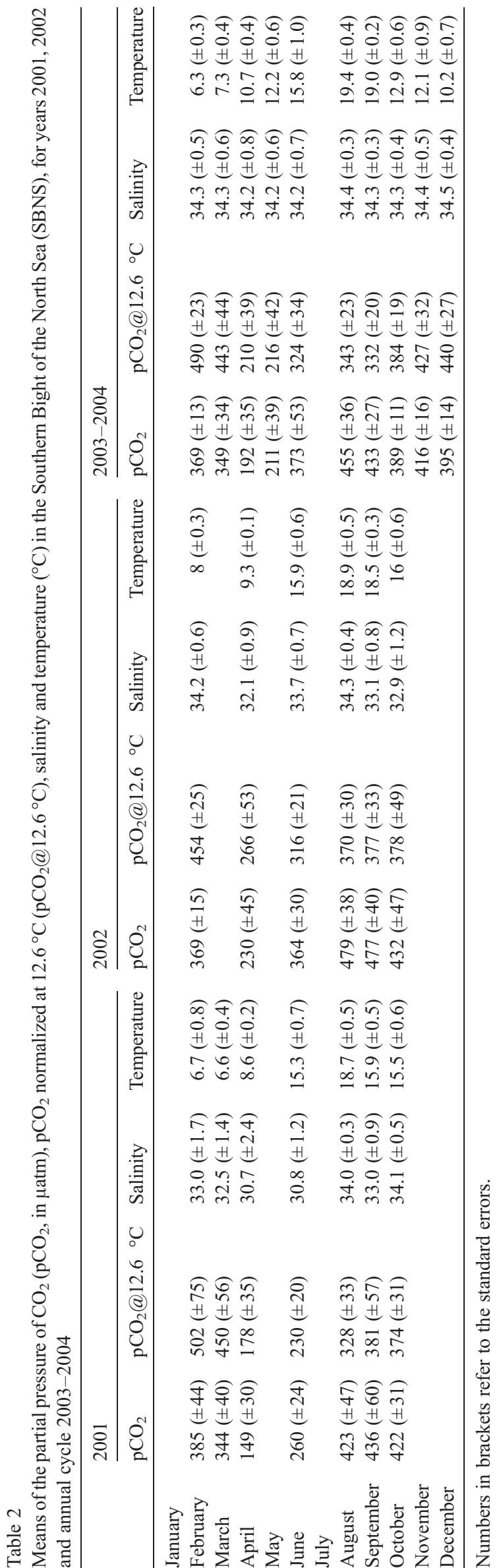

\subsection{Biological effects versus temperature}

In order to separate and assess the seasonal effects of biological processes and temperature on the $\mathrm{pCO}_{2} \mathrm{dy}-$ namics over an annual cycle, the method developed by Takahashi et al. (2002) was applied on the data from June 2003 to May 2004. This method gives a qualitative information on the effect of temperature and the "net biology effect" on the $\mathrm{pCO}_{2}$ dynamics. As defined by Takahashi et al. (2002), the "net biology effect" (Eq. (3)) includes all the biogeochemical processes acting on net $\mathrm{CO}_{2}$ utilization (primary production, respiration), changes of TA by nitrate consumption, airsea $\mathrm{CO}_{2}$ exchange and changes of DIC by advection of different waters and freshwaters discharges. Following the Takahashi et al. (2002) method, the temperature effect was removed from the observed $\mathrm{pCO}_{2}$ by normalizing the $\mathrm{pCO}_{2}$ data at the annual mean temperature (12.6 ${ }^{\circ} \mathrm{C}$ for 2003-2004), Eq. (3). The effect of temperature is assessed by perturbing the mean annual $\mathrm{pCO}_{2}$ (358 $\mu \mathrm{atm}$ ) with the difference between annual mean temperature and observed temperature, Eq. (4). Biological $(B)$ and thermal $(T)$ effects on the $\mathrm{pCO}_{2}\left(\mathrm{pCO}_{2 B}\right.$ and $\mathrm{pCO}_{2 T}$ ) were thus calculated for each month from June 2003 to May 2004 according to the following equations:

$$
\begin{aligned}
p \mathrm{CO}_{2 B}= & p \mathrm{CO}_{2}\left(T_{\text {mean }}\right) \\
= & p \mathrm{CO}_{2} \cdot \exp \left(0.0423 \cdot\left(T_{\text {mean }}-T_{\text {obs }}\right)\right) \\
p \mathrm{CO}_{2 T}= & p \mathrm{CO}_{2}\left(T_{\text {obs }}\right)=\left(\text { mean annual } p \mathrm{CO}_{2}\right) \\
& \times \exp \left(0.0423 \cdot\left(T_{\text {obs }}-T_{\text {mean }}\right)\right)
\end{aligned}
$$

where $T_{\text {mean }}$ is the mean annual temperature $\left(12.6{ }^{\circ} \mathrm{C}\right)$ and $T_{\mathrm{obs}}$ is the in-situ temperature.

The effect of $B$ and $T$ on the amplitude of the seasonal variations of $\mathrm{pCO}_{2}$ are determined, respectively, from the amplitude of $\mathrm{pCO}_{2 B}$ and $\mathrm{pCO}_{2 T}$. A $T / B$ ratio greater than 1 implies the dominance of temperature effects over biological processes on the $\mathrm{pCO}_{2}$ dynamics. Fig. 5 shows the seasonal variations of the $\delta \mathrm{pCO}_{2}$, $\delta \mathrm{pCO}_{2 B}, \delta \mathrm{pCO}_{2 T}$ (differences calculated using the February values, which have the lowest temperatures and biological activities). Maximum $\left|\delta \mathrm{pCO}_{2 B}\right|$ values were observed during the spring phytoplanktonic bloom (April-May; $\sim 270 \mu \mathrm{atm}$ ) while maximum $\delta \mathrm{pCO}_{2 T}$ values were observed in August $(\sim 200 \mu \mathrm{atm})$. From February to May, biological $\mathrm{CO}_{2}$ draw down, i.e., photosynthesis, was the main driver of the surface waters $\mathrm{pCO}_{2}$ dynamics, as $T / B \sim 0.29(T-B=-195)$, whereas from June to December temperature was the main driver of $\mathrm{pCO}_{2}$ dynamics $(T / B=1.34 ; T-B=39)$. Over an 


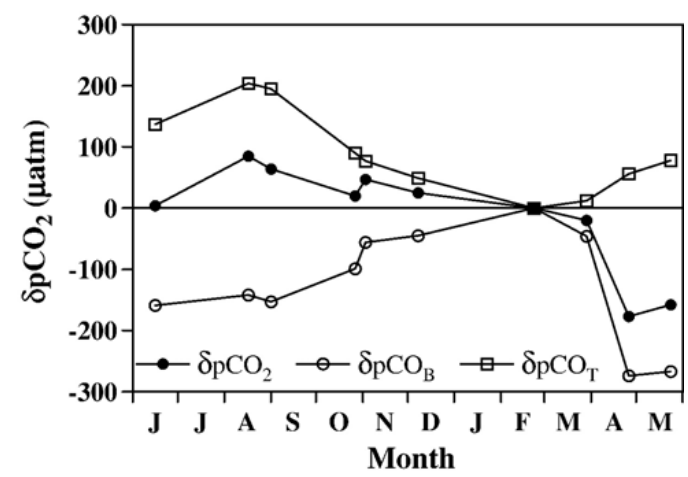

Fig. 5. $8 \mathrm{pCO}_{2}$ (filled circles) $\delta \mathrm{pCO}_{2 T}$ (filled squares) and $\delta \mathrm{pCO}_{2 B}$ (empty circles) for the Southern Bight of the North Sea (SBNS), calculated as the difference with February, from June 2003 to May 2004.

annual cycle, the dynamics of the surface $\mathrm{pCO}_{2}$ in the SBNS was mainly controlled by biological activities, with a $T / B$ ratio of $0.74(T-B=-70)$. As stated above, all biogeochemical processes such as estuarine inputs are inherently included in the term "Biological" in the $\mathrm{pCO}_{2 B}$ computations. However, when estuarine plumes are excluded in the computations (data with salinity $\geq 34$, data not shown) the annual $T / B$ ratio is rather similar (0.79).

These results differ from those reported by Thomas et al. (2005a) who suggested that the surface $\mathrm{pCO}_{2}$ dynamics in the SBNS was seasonally controlled by temperature rather than by biology with maximum $\left|\delta \mathrm{pCO}_{2 B}\right|$ and $\delta \mathrm{pCO}_{2 T}$ of 100 and $135 \mu \mathrm{atm}$, respec- tively, and a $T / B$ of 1.35 . Fig. 7 shows that the late May 2002 cruise from the Thomas et al. (2005a) study was carried out during the declining phase of the phytoplankton bloom, and that this data-set does not adequately account for the strong $\mathrm{CO}_{2}$ under-saturation in the SBNS typically observed in mid-April during the peak of the phytoplankton bloom (Reid et al., 1990; Borges and Frankignoulle, 1999, 2002, 2003; Frankignoulle and Borges, 2001; Rousseau et al., 2002; Gypens et al., 2004; Schiettecatte et al., 2006).

\subsection{Net ecosystem production}

An ecosystem is defined as autotrophic if NEP is positive, i.e. when gross primary production (GPP) exceeds community respiration (CR), and as heterotrophic when CR exceeds GPP (Odum, 1956). There are several ways to appraise the metabolic status of an ecosystem, as reviewed by Gazeau et al. (2004) for European coastal zones. Here, we used a simple approach to compute NEP (mmol $\mathrm{C} \mathrm{m}^{-2}$ day $^{-1}$ ) based on the temporal DIC variations according to the Eq. (2), from August 2003 to May 2004 (Table 3 and Fig. 6).

The SBNS was heterotrophic from mid-August to March ( -6.0 to $-23.9 \mathrm{mmol} \mathrm{C} \mathrm{m}^{-2}$ day $^{-1}$ ), and was autotrophic from April to May, with strongest NEP value in April (161.3 mmol $\mathrm{C} \mathrm{m}^{-2}$ day $\left.^{-1}\right)$. At an annual scale the SBNS was strongly autotrophic at a rate of $\sim 17.3$ mmol $\mathrm{C} \mathrm{m}^{-2}$ day $^{-1}$. When estuarine plumes were excluded from the computations (data not shown),

Table 3

Monthly averaged dissolved inorganic carbon (DIC in mmol m${ }^{-3}$ ), density (in $\mathrm{kg} \mathrm{m}^{-3}$ ), air-sea $\mathrm{CO}_{2}$ fluxes $\left(F_{\mathrm{CO}_{2}}\right.$ in mmol $\mathrm{C} \mathrm{m}^{-2}$ day $\left.{ }^{-1}\right)$ computed with the $k$ parameterization given by Nightingale et al. (2000), time interval between cruises ( $\Delta t$ in days) and net ecosystem production (NEP in mmol $\mathrm{C} \mathrm{m}^{-2}$ day $^{-1}$ ) in the Southern Bight of the North Sea (SBNS), calculated for a mean depth of $30 \mathrm{~m}$ from the annual cycle from August 2003 to May 2004

\begin{tabular}{|c|c|c|c|c|c|}
\hline Cruise & $\mathrm{DIC}\left(\mathrm{mmol} \mathrm{m}^{-3}\right)$ & Density $\left(\mathrm{kg} \mathrm{m}^{-3}\right)$ & $F_{\mathrm{CO}_{2}}\left(\mathrm{mmol} \mathrm{C} \mathrm{m}{ }^{-2}\right.$ day $\left.^{-1}\right)$ & $\Delta t(d)$ & $\operatorname{NEP}\left(\mathrm{mmol} \mathrm{C} \mathrm{m}{ }^{-2}\right.$ day $\left.^{-1}\right)$ \\
\hline \multirow[t]{2}{*}{ August } & $2128(21)$ & $1024.4(0.2)$ & $6.8(0.2)$ & & \\
\hline & & & & 15 & -23.9 \\
\hline \multirow[t]{2}{*}{ September } & $2137(27)$ & $1024.3(0.4)$ & $4.2(0.2)$ & & \\
\hline & & & & 56 & -23.5 \\
\hline \multirow[t]{2}{*}{ October } & $2173(31)$ & $1025.9(0.3)$ & $4.5(0.0)$ & & \\
\hline & & & & 42 & -14.2 \\
\hline \multirow[t]{2}{*}{ December } & $2189(29)$ & $1026.6(0.2)$ & $1.4(0.1)$ & & \\
\hline & & & & 77 & 0.4 \\
\hline \multirow{2}{*}{ February } & $2188(13)$ & $1026.8(0.3)$ & $-2.1(0.1)$ & & \\
\hline & & & & 35 & -6.0 \\
\hline \multirow[t]{2}{*}{ March } & $2200(32)$ & $1026.5(0.5)$ & $-5.3(0.3)$ & & \\
\hline & & & & 28 & 161.3 \\
\hline \multirow[t]{2}{*}{ April } & $2061(39)$ & $1025.9(0.7)$ & $-19.1(0.1)$ & & \\
\hline & & & & 28 & 27.2 \\
\hline May & $2050(24)$ & $1025.8(0.5)$ & $-13.1(0.0)$ & & \\
\hline Mean & & & & & 17.3 \\
\hline
\end{tabular}

Numbers in parenthesis refer to standard error. 


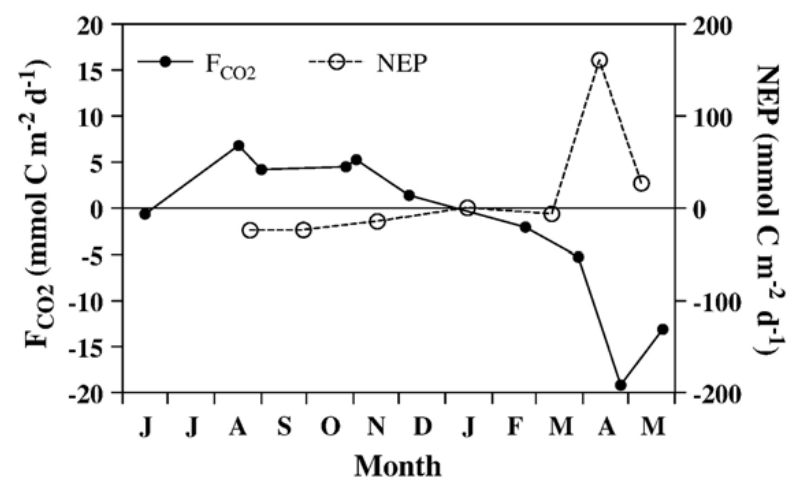

Fig. 6. Estimated net ecosystem production (NEP in $\mathrm{mmol} \mathrm{C} \mathrm{m} \mathrm{m}^{-2}$ day ${ }^{-1}$, empty circles) and monthly air-sea $\mathrm{CO}_{2}$ fluxes $\left(F_{\mathrm{CO}_{2}}\right.$, mmol C $\mathrm{m}^{-2}$ day $^{-1}$, filled circles) computed using the gas transfer velocity parameterization given by Nightingale et al. (2000) for the Southern Bight of the North Sea (SBNS) from June 2003 to May 2004.

annually integrated NEP remained relatively unchanged (17.2 $\mathrm{mmol} \mathrm{C} \mathrm{m}^{-2} \mathrm{day}^{-1}$ ). However, the SBNS (excluding the estuarine plumes) was autotrophic from midFebruary to May (14.7 to $139.7 \mathrm{mmol} \mathrm{C} \mathrm{m}^{-2}$ day $^{-1}$ ), with strongest values in April $\left(139.7 \mathrm{mmol} \mathrm{C} \mathrm{m}^{-2}\right.$ day $\left.^{-1}\right)$. Heterotrophy was lower from August to mid-January $\left(-12.9\right.$ versus $-20.5 \mathrm{mmol} \mathrm{C} \mathrm{m}^{-2} \mathrm{day}^{-1}$, mean NEP values for that period when excluding and including estuarine plumes, respectively). Estuarine plumes receive nutrient inputs that can support higher GPP, but during summer heterotrophy is also stronger due to the higher organic matter availability from the spring phytoplankton blooms, and to a lesser extent due to the inputs of organic matter from inner estuaries. These trends in NEP are in agreement with previous studies in the $\mathrm{BCZ}$ and the Scheldt estuarine plume (Gypens et al., 2004; Schiettecatte et al., 2006).

These NEP values at annual scale and for the productive period (from February to August, $39.6 \mathrm{mmol}$ $\mathrm{C} \mathrm{m}^{-2}$ day $^{-1}$, including estuarine plumes) are slightly higher but in fair agreement with those reported in the SBNS by Bozec et al. (2006), respectively, 10.1 and
$33.3 \mathrm{mmol} \mathrm{C} \mathrm{m}{ }^{-2}$ day $^{-1}$. These authors estimated NEP from the data-sets of Thomas et al. (2004, 2005a,b), with a DIC mass balance at the scale of the whole North Sea, based on the water flows from European Regional Seas Ecosystem Model (Lenhart and Pohlmann, 1997) and using International Council for the Exploration of the Sea (ICES) boxes (the SBNS is divided into 2 ICES boxes). As mentioned above, the peak of phytoplanktonic bloom was not fully captured by the underlying data-sets, which can explain the slightly higher NEP values from our study, although the differences could also be due the methodological approaches or interannual variability. Our annual integrated NEP value is also in good agreement with the NEP value of $15.3 \mathrm{mmol}$ $\mathrm{C} \mathrm{m}^{-2}$ day $^{-1}$ computed for the SBNS by Gattuso et al. (1998) based on the GPP and CR incubation based measurements of Joiris et al. (1982).

\subsection{Air-sea $\mathrm{CO}_{2}$ fluxes}

From February to June, the SNBS was a sink of atmospheric $\mathrm{CO}_{2}$ ranging from -0.6 to $-19.1 \mathrm{mmol} \mathrm{C}$ $\mathrm{m}^{-2}$ day $^{-1}$ (respectively, in June and April), using the Nightingale et al. (2000) $k$ parameterization, in agreement with its trophic status (Fig. 6). From August to December, the SNBS was a source of $\mathrm{CO}_{2}$ to the atmosphere raging from 1.4 to $6.8 \mathrm{mmol} \mathrm{C} \mathrm{m}^{-2}$ day $^{-1}$, also in agreement with its trophic status. On an annual scale, the SBNS was a net sink for atmospheric $\mathrm{CO}_{2}$ at a rate of $-0.65 \mathrm{~mol} \mathrm{C} \mathrm{m}^{-2} \mathrm{yr}^{-1}$. When estuarine plumes are excluded from the computations, annually integrated $F_{\mathrm{CO}_{2}}$ increased by about $20 \%$ (annual sink for atmospheric $\mathrm{CO}_{2}$ at a rate of $-0.83 \mathrm{~mol} \mathrm{C} \mathrm{m}^{-2} \mathrm{yr}^{-1}$; data not shown).

Previous studies carried out in the SBNS which attempted to asses its role as a sink or source of $\mathrm{CO}_{2}$ on an annual scale are presented in Table 4. Although the dataset from Frankignoulle and Borges (2001) did not cover a complete annual cycle, these authors hypothesized that

Table 4

Comparison of air-sea $\mathrm{CO}_{2}$ fluxes $\left(F_{\mathrm{CO}_{2}}\right.$ in $\mathrm{mmol} \mathrm{C} \mathrm{m}^{-2}$ day $\left.{ }^{-1}\right)$ in the Southern Bight of the North Sea (SBNS), from the present study and literature, computed using the gas transfer velocity parameterization from Wanninkhof (1992), and Wanninkhof and McGillis (1999), referred, respectively, as $\mathrm{W}$ and $\mathrm{W}$ and $\mathrm{McG}$

\begin{tabular}{|c|c|c|c|c|c|c|c|}
\hline \multirow[t]{2}{*}{ Month } & \multicolumn{3}{|c|}{ This study } & \multicolumn{2}{|c|}{$\begin{array}{l}\text { Frankignoulle and } \\
\text { Borges }(2001)\end{array}$} & \multicolumn{2}{|c|}{ Thomas et al. (2004) } \\
\hline & $\Delta \mathrm{pCO}_{2}$ & $F_{\mathrm{CO}_{2}}[\mathrm{~W}]$ & $F_{\mathrm{CO}_{2}}[\mathrm{~W}$ and $\mathrm{McG}]$ & $\Delta \mathrm{pCO}_{2}$ & $F_{\mathrm{CO}_{2}}[\mathrm{~W}]$ & $\Delta \mathrm{pCO}_{2}$ & $F_{\mathrm{CO}_{2}}[\mathrm{~W}$ and $\mathrm{McG}]$ \\
\hline September & 55 & 5.1 & 3.8 & & & 17.7 & 1.2 \\
\hline November & 31 & 6.7 & 6.8 & 5 & 2.5 & 16.5 & 2.4 \\
\hline April & -182 & -23.7 & -20.7 & -105 & -58.4 & & \\
\hline May & -170 & -15.7 & -12.2 & -170 & -27.1 & -17.3 & -2.4 \\
\hline
\end{tabular}


the SBNS was an annual $\mathrm{CO}_{2}$ sink. The $F_{\mathrm{CO}_{2}}$ values for April 1996 and May 1995 computed by Frankignoulle and Borges (2001) are about 2 times stronger than those computed in this study, due to differences in wind speed. Frankignoulle and Borges (2001) used in their computations a mean $u_{10}$ of $9.6 \mathrm{~m} \mathrm{~s}^{-1}$ in April 1996 against $6.2 \mathrm{~m} \mathrm{~s}^{-1}$ in April 2004. In May 1995 and 2004, average $u_{10}$ were respectively 5.1 and $5.3 \mathrm{~m} \mathrm{~s}^{-1}$ and $\Delta \mathrm{pCO}_{2}$ values were similar. Frankignoulle and Borges (2001) computed $F_{\mathrm{CO}_{2}}$ with instantaneous $u_{10}$ ( 1 min frequency) obtained during the 2 days transect, whereas $F_{\mathrm{CO}_{2}}$ in this study was computed with hourly $u_{10}$ data measured during the full duration of the cruise. The differences in $F_{\mathrm{CO}_{2}}$ are due to the strong non-linear relationship between $k$ and $u_{10}$, which can lead to significant differences due to the wind speed frequency distribution and the averaging methods used (e.g. Bates and Merlivat, 2001; Lüger et al., 2006).

The high temporal resolution of the present study allows us to provide evidence that the recent seasonal study by Thomas et al. (2004) did not capture the maximum extent of the $\mathrm{pCO}_{2}$ minimum during spring in the SBNS. According to this study the SBNS (corresponding to the box 2 in their study) was an annual source of $\mathrm{CO}_{2}$ at a rate of $0.2 \mathrm{~mol} \mathrm{C} \mathrm{m}^{-2} \mathrm{yr}^{-1}$, while the present study identifies the SBNS as a $\mathrm{CO}_{2}$ sink on an annual scale of $-0.7 \mathrm{~mol} \mathrm{C} \mathrm{m}^{-2} \mathrm{yr}^{-1}$ (Table 3).

\subsection{Inter-annual variability of $\mathrm{pCO}_{2}$}

Fig. 7 shows for the SBNS the annual cycle of mean surface $\mathrm{pCO}_{2}$ and $\mathrm{pCO}_{2} @ 12.6{ }^{\circ} \mathrm{C}$ based on data obtained from June 2003 to May 2004, with additional data from 2001 to 2002. Table 2 gives the means (and standard errors) of the surface $\mathrm{pCO}_{2}, \mathrm{pCO}_{2} @ 12.6{ }^{\circ} \mathrm{C}$, salinity and temperature for data gathered from 2001 to 2004. Clear inter-annual variability was observed which in some cases can be explained by temperature, biological activities and mean salinity (e.g. estuaries discharges with higher DIC content). Temperature effect on the $\mathrm{pCO}_{2}$ dynamics from one year to another is shown by the comparison of $\mathrm{pCO}_{2}$ and $\mathrm{pCO}_{2} @ 12.6{ }^{\circ} \mathrm{C}$ during summer (e.g. mid-August 2001-2003; mid-September 2001-2002). In other cases inter-annual variability of mean $\mathrm{pCO}_{2}$ was related to differences in biological activity. The largest differences occurred during the spring bloom when mean $\mathrm{pCO}_{2}$ values in April 2001 and 2002 were, respectively, $\sim 40 \mu$ atm lower and higher than in 2004. Inter-annual differences among the mean $\mathrm{pCO}_{2}$ are consistent with Sea-viewing Wide Fieldof-view Sensor (SeaWiFS) level-3 chlorophyll-a data (http://reason.gsfc.nasa.gov/Giovanni/). Concentration
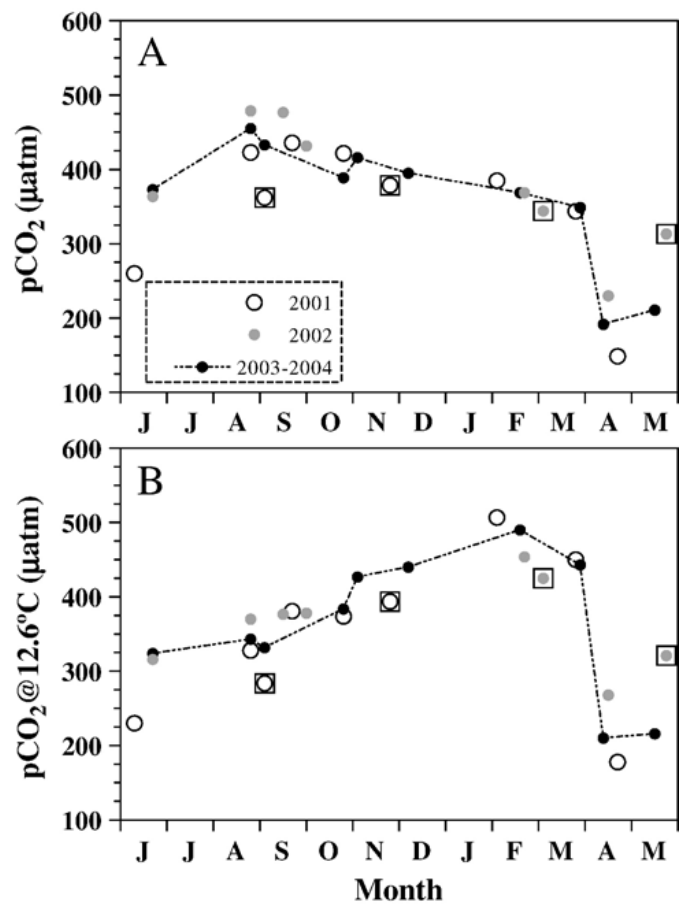

Fig. 7. Mean surface partial pressure of $\mathrm{CO}_{2}\left(\mathrm{pCO}_{2}\right)$ and $\mathrm{pCO}_{2}$ normalized to a temperature of $12.6{ }^{\circ} \mathrm{C}\left(\mathrm{pCO}_{2} @ 12.6{ }^{\circ} \mathrm{C}\right)$ in the Southern Bight of the North Sea (SBNS), gathered from 2001 to 2004. Annual cycle from June 2003 to May 2004 is shown as black circles, $\mathrm{pCO}_{2}$ measured during 2001 and 2002 are represented respectively by empty and grey circles. Data from Thomas et al. (2004) are identified with a square.

in chlorophyll-a (data not shown) was higher in April 2001 (up to $25 \mu \mathrm{g}^{-1}$ ), than in 2002 and 2004 for the same month (around $10 \mu \mathrm{g} \mathrm{l}^{-1}$ ), in agreement with the observed mean $\mathrm{pCO}_{2}$ in April between the different years. From 2001 to 2004, phytoplankton biomass as shown by chlorophyll-a was variable from year to year in amplitude, but with a recurrent maximum during April. During spring 2004, chlorophyll-a increased from mid February and fluctuated around $10 \mu \mathrm{g} 1^{-1}$ until late June, whereas the phytoplanktonic bloom in 2002 last from March to May, with a moderate bloom during summer. Differences in mean $\mathrm{pCO}_{2}$ for spring 2002 and 2004 could be related to both concentration in chlorophyll-a, mean salinity and/or temperature. Lower salinity (as it is the case for April 2002 compared to April 2004) would imply higher concentrations of nutrients and suspended matter.

The decrease of $\mathrm{pCO}_{2}$ between mid-and late August 2001 could be due to a moderate summer bloom of diatoms (Reid et al., 1990; Gypens et al., 2004 from observations from 1996-1999), as suggested by oxygen concentrations slightly above atmospheric equilibrium for stations close to estuarine mouths in late August 2001 (Bozec et al., 2005). The increase of $\mathrm{pCO}_{2}$ from 
late August to mid-September 2001 might be related to a decrease of the mean salinity in the whole area from 34 to 33, respectively (Table 2), and related increase of DIC content in the estuarine plumes and/or to the degradation of organic matter produced by the bloom in late August.

Based on the MIRO biogeochemical model (Lancelot et al., 2005) constrained by global solar radiation, seawater temperature and riverine nutrients loads, over the period 1989-2003, Gypens et al. (2007) suggested that inter-annual variability in diatom biomass depends on both meteorological conditions (light and temperature) and nutrient loads, whereas Phaeocystis sp. blooms are mainly controlled by nutrient availability. $\mathrm{A} \mathrm{CO}_{2}$ module was coupled to the MIRO model by Gypens et al. (2004) and validated at a single fixed station in the $\mathrm{BCZ}$. This study showed that inter-annual variations of the $\mathrm{pCO}_{2}$ in the Belgian coastal waters are strongly driven by nutrient availability and amplitude and timing of biological activity, owing to inter-annual variations of freshwater discharge and temperature.

\section{Summary and conclusions}

A monthly survey from June 2003 to May 2004 in the SBNS shows that the seasonal variations of the surface distribution of $\mathrm{pCO}_{2}$ are mainly controlled by biological activity rather than by temperature. Comparison with data obtained in 2001 and 2002 shows that a relatively important inter-annual variability of $\mathrm{pCO}_{2}$ occurs in the SBNS. This inter-annual variability is partly due to temperature but also to biological activity, in particular during the periods of the phytoplankton blooms in April and May. The SBNS is a sink for atmospheric $\mathrm{CO}_{2}\left(-0.7 \mathrm{~mol} \mathrm{C} \mathrm{m}{ }^{-2} \mathrm{yr}^{-1}\right)$ mainly driven by autotrophic processes, as shown from the simple computation of NEP based on the temporal variation of DIC.

These results are in disagreement with the conclusions on air-sea $\mathrm{CO}_{2}$ exchange based on the Thomas et al. $(2004,2005 \mathrm{a})$ data-set that consists in 4 cruises in the whole North Sea. This disagreement is due to the fact that the May 2002 cruise in the data-set of Thomas et al. $(2004,2005 \mathrm{a})$ was carried out during the declining phase of the phytoplankton bloom, implying that this data-set does not adequately account for the strong $\mathrm{CO}_{2}$ under-saturation in the SBNS typically observed in midApril during the peak of the phytoplankton bloom. The study by Thomas et al. $(2004,2005 \mathrm{a})$ aimed at a basin wide study of the North Sea with a high vertical and horizontal resolution of dissolved inorganic carbon variables and nutrients. This brings to the fore the difficulty of reconciling high spatial and temporal resolution for field based studies of biogeochemical variables and processes in coastal ecosystems.

High temporal resolution of measurements of $\mathrm{pCO}_{2}$ is clearly a master key to provide reliable annually integrated air-sea $\mathrm{CO}_{2}$ fluxes, and to asses the different drivers of $\mathrm{pCO}_{2}$, particularly in highly dynamic and heterogeneous coastal environments, such as estuarine plumes or proximal continental shelves (e.g. Boehme et al., 1998; DeGrandpre et al., 2002; Friederich et al., 2002; Schiettecatte et al., 2006). On the other hand, basin wide regional coverage is required to quantify and understand large scale carbon cycling. Thus, Thomas et al. (2004) showed that the northern part of the North Sea followed the paradigm of the "continental shelf pump" as proposed by Tsunogai et al. (1999). This is due to the sequestration below the thermocline of the spring synthesized organic matter, which by respiratory processes enriches the deeper waters in DIC, that are subsequently transported to the adjacent North Atlantic. In contrast, DeGrandpre et al. (2002) showed that the Middle Atlantic Bight owed its potential to absorb $\mathrm{CO}_{2}$ to windthermodynamic effects. As suggested by Thomas et al. (2004, 2005a) the permanently well-mixed SBNS does not follow either of these conceptual schemes of carbon sequestration. However, it seems to be an efficient biological pump for $\mathrm{CO}_{2}$ due to the decoupling in time of biological processes (primary production at springtime and respiration processes in summer) combined to the relatively rapid flushing time in the area ( $\sim 70$ days). This combination might allow for a fraction of the organic matter synthesized during spring to escape remineralization within the area, and to be exported towards the German Bight.

\section{Acknowledgments}

We thank the crew of the R.V. Belgica for their assistance during the cruises, Management Unit of the North Sea Mathematical Models (MUMM) for thermosalinograph data, Martine Leermaekers, Anna Lourantou, Teodora Ortega Diaz, François Paquay and Marianna Ribas Ribas, for their help in sampling, Frédéric Gazeau for comments during the elaboration of the manuscript, Bruno Delille and Fabian Lenartz for help with remote sensing data. This research was supported by the European Union in the framework of the EUROTROPH project (contract \# EVK3-CT-200000040), and the CARBOOCEAN project (contract \# 511176-2), by the Belgian Science Policy in the framework of the CANOPY project (contract \# EV/12/20C), the SOLAS.be network (contract \# OA/00/025), and by the Fonds National de la Recherche Scientifique 
(contracts \# 2.4545.02, \# F.4513.06), where AVB is a research associate. This is MARE publication $n^{\circ} 103$.

\section{References}

Bakker, D.C.E., de Baar, H.J.W., de Wilde, H.P.J., 1996. Dissolved carbon dioxide in Dutch coastal waters. Marine Chemistry 55, 247-263.

Bates, N.R., Merlivat, L., 2001. The influence of short-term wind variability on air-sea $\mathrm{CO}_{2}$ exchange. Geophysical Research Letters 28, 3281-3284.

Benson, B.B., Krause, D., 1984. The concentration and isotopic fractionation of oxygen dissolved in freshwater and seawater in equilibrium with the atmosphere. Limnology and Oceanography 29, 620-632.

Boehme, S.E., Sabine, C.L., Reimers, C.E., 1998. $\mathrm{CO}_{2}$ fluxes from a coastal transect: a time-series approach. Marine Chemistry 63, $49-67$.

Borges, A.V., 2005. Do we have enough pieces of the jigsaw to integrate $\mathrm{CO}_{2}$ fluxes in the coastal ocean? Estuaries 28 (1), 3-27.

Borges, A.V., Frankignoulle, M., 1999. Daily and seasonal variations of the partial pressure of $\mathrm{CO}_{2}$ in surface seawater along Belgian and southern Dutch coastal areas. Journal of Marine Systems 19, 251-266.

Borges, A.V., Frankignoulle, M., 2002. Distribution and air-water exchange of carbon dioxide in the Scheldt plume off the Belgian coast. Biogeochemistry 59, 41-67.

Borges, A.V., Frankignoulle, M., 2003. Distribution of surface carbon dioxide and air-sea exchange in the English Channel and adjacent areas. Journal of Geophysical Research-Oceans 108 (C5), 3140. doi:10.1029/2000JC000571.

Borges, A.V., Delille, B., Frankignoulle, M., 2005. Budgeting sinks and sources of $\mathrm{CO}_{2}$ in the coastal ocean: diversity of ecosystems counts. Geophysical Research Letters 32, L14601. doi:10.1029/ 2005 GL023053.

Bozec, Y., Thomas, H., Elkalay, K., de Baar, H.J.W., 2005. The continental shelf pump for $\mathrm{CO}_{2}$ in the North Sea - evidence from summer observations. Marine Chemistry 93, 131-137.

Bozec, Y., Thomas, H., Schiettecatte, L.-S., Borges, A.V., Elkalay, K., de Baar, H.J.W., 2006. Assessment of the processes controlling the seasonal variations of dissolved inorganic carbon in the North Sea. Limnology and Oceanography 51 (6), 2746-2762.

Brewer, P.G., Goldman, J.C., 1976. Alkalinity changes generated by phytoplankton growth. Limnology and Oceanography 21, 108-117.

Chen, C.T.A., 2004. Exchanges of carbon in the coastal seas. In: Field, C.B., Raupach, M.R. (Eds.), The Global Carbon Cycle: Integrating Humans, Climate, and the Natural World, SCOPE. Island Press, Washington DC, pp. 341-350.

Copin-Montégut, C., 1988. A new formula for the effect of temperature on the partial pressure of carbon dioxide in seawater. Marine Chemistry 25, 29-37.

Copin-Montégut, C., 1989. A new formula for the effect of temperature on the partial pressure of carbon dioxide in seawater, corrigendum. Marine Chemistry 27, 143-144.

De Galan, S., Elskens, M., Goeyens, L., Pollentier, A., Brion, N., Baeyens, W., 2004. Spatial and temporal trends in nutrient concentrations in the Belgian Continental area of the North Sea during the period 1993-2000. Estuarine Coastal and Shelf Science 61, $517-528$

DeGrandpre, M.D., Olbu, G.J., Beatty, C.M., Hammar, T.R., 2002. Air-sea $\mathrm{CO}_{2}$ fluxes on the US Middle Atlantic Bight. Deep-
Sea Research. Part II-Topical Studies in Oceanography 49, $4355-4367$.

Dickson, A.G., 1990. Thermodynamics of the dissociation of boric acid in synthetic sea water from 273.15 to $298.15 \mathrm{~K}$. Deep-sea research. Part A, Oceanographic Research Papers 37, 755-766.

Dickson, A.G., Goyet, C., 1994. Handbook of methods for the analysis of the various parameters of the carbon dioxide system in sea water. In: Dickson, A.G., Goyet, C. (Eds.), Carbon Dioxide Information Analysis Center. Tenn, Oak ridge.

Frankignoulle, M., Borges, A.V., 2001. European continental shelf as a significant sink for atmospheric carbon dioxide. Global Biogeochemical Cycles 15, 569-576.

Frankignoulle, M., Borges, A.V., Biondo, R., 2001. A new design of equilibrator to monitor carbon dioxide in highly dynamic and turbid environments. Water Research 35, 1344-1347.

Friederich, G.E., Walz, P.M., Burczynski, M.G., Chavez, F.P., 2002. Inorganic carbon in the central California upwelling system during the 1997-1999 El Niño-La Niña event. Progress in Oceanography 54 (1-4), 185-203.

Gattuso, J.-P., Frankignoulle, M., Wollast, R., 1998. Carbon and carbonate metabolism in coastal aquatic ecosystems. Annual Reviews of Ecological Systems 29, 405-434.

Gazeau, F., Smith, S.V., Gentili, B., Frankignoulle, M., Gattuso, J.-P., 2004. The European coastal zone: characterization and first assessment of ecosystem metabolism. Estuarine Coastal and Shelf Science 60, 673-694.

GLOBALVIEW- $\mathrm{CO}_{2}, 2006$ : Cooperative Atmospheric Data Integration Project - Carbon Dioxide. CD-ROM, NOAA GMD, Boulder, Colorado [Also available on Internet via anonymous FTP to ftp. cmdl.noaa.gov, Path: ccg/co2/GLOBALVIEW].

Gypens, N., Lancelot, C., Borges, A.V., 2004. Carbon dynamics and $\mathrm{CO}_{2}$ air-sea exchanges in the eutrophicated coastal waters of the Southern Bight of the North Sea: a modeling study. Biogeosciences 1, 561-589.

Gypens, N., Lacroix, G., Lancelot, C., 2007. Causes of variability in diatom and Phaeocystis blooms in Belgian coastal waters between 1989 and 2003: a model study. Journal of Sea Research 57 (1), 19-35.

Hoppema, J.M.J., 1991. The seasonal behavior of carbon-dioxide and oxygen in the coastal North-Sea along the Netherlands. Netherlands Journal of Sea Research 28 (3), 167-179.

Joiris, C., Billen, G., Lancelot, C., Daro, M.H., Mommaerts, J.-P., Bertels, A., Bossicart, M., Nijs, J., 1982. A budget of carbon cycling in the Belgian coastal zone: relative roles of zooplankton, bacterioplankton and benthos in the utilization of primary production. Netherlands Journal of Sea Research 16, 260-275.

Kempe, S., Pegler, K., 1991. Sinks and sources of $\mathrm{CO}_{2}$ in coastal seas-The North Sea. Tellus. Series B, Chemical and Physical Meteorology 43, 224-235.

Lancelot, C., Spitz, Y., Gypens, N., Ruddick, K., Becquevort, S., Rousseau, V., Lacroix, G., Billen, G., 2005. Modelling diatom and Phaeocystis blooms and nutrient cycles in the Southern Bight of the North Sea: the MIRO model. Marine Ecology. Progress Series 289, 63-78.

Lenhart, H., Pohlmann, T., 1997. The ICES-boxes approach in relation to results of a North Sea circulation model. Tellus 49A, 139-160.

Lüger, H., Wanninkhof, R., Wallace, D.W.R., Körtzinger, A., 2006. $\mathrm{CO}_{2}$ fluxes in the subtropical and subarctic North Atlantic based on measurements from a volunteer observing ship. Journal of Geophysical Research-Oceans 111, C06024. doi:10.1029/2005JC003101.

Nightingale, P.D., Malin, G., Law, C.S., Watson, A.J., Liss, P.S., Liddicoat, M.I., Boutin, J., Upstill-Goddard, R.C., 2000. In situ 
evaluation of air-sea gas exchange parameterizations using novel conservative and volatile tracers. Global Biogeochemical Cycles $14,373-387$.

Odum, H.T., 1956. Primary production in flowing waters. Limnology and Oceanography 1, 102-117.

OSPARCOM, 2002. Quality Status Report 2000. OSPAR Commission, London. http://www.ospar.com.

Reid, P.C., Lancelot, C., Gieskes, W.W.C., Hagmeier, E., Weichart, G., 1990. Phytoplankton of the North Sea and its dynamics - a review. Netherlands Journal of Sea Research 26, 295-331.

Rousseau, V., Leynaert, A., Daoud, N., Lancelot, C., 2002. Diatom succession, silicification and silicic acid availability in Belgian coastal waters (Southern North Sea). Marine Ecology. Progress Series 236, 61-73.

Roy, R.N., Roy, L.N., Vogel, K.M., Portermoore, C., Pearson, T., Good, C.E., Millero, F.J., Campbell, D.M., 1993. The dissociationconstants of carbonic-acid in seawater at salinities 5 to 45 and temperatures 0 degrees-C to 45 degrees-C. Marine Chemistry 44 , 249-267.

Sabine, C.L., Feely, R.A., Gruber, N., Key, R.M., Lee, K., Bullister, J.L., Wanninkhof, R., Wong, C.S., Wallace, D.W.R., Tilbrook, B., Millero, F.J., Peng, T.H., Kozyr, A., Ono, T., Rios, A.F., 2004. The oceanic sink for anthropogenic $\mathrm{CO}_{2}$. Science 305, 367-371.

Schiettecatte, L.-S., Gazeau, F., van der Zee, C., Brion, N., Borges, A.V., 2006. Time series of the partial pressure of carbon dioxide (2001-2004) and preliminary inorganic carbon budget inn the Scheldt plume (Belgian coastal waters). Geochemistry, Geophysics, Geosystems (G3) 7, Q06009. doi:10.1029/2005GC001161.

Takahashi, T., Sutherland, S.C., Sweeney, C., Poisson, A., Metzl, N., Tilbrook, B., Bates, N., Wanninkhof, R., Feely, R.A., Sabine, C., Olafsson, J., Nojiri, Y., 2002. Global sea-air $\mathrm{CO}_{2}$ flux based on climatological surface ocean $\mathrm{pCO}_{2}$, and seasonal biological and temperature effects. Deep-Sea Research. Part II-Topical Studies in Oceanography 49, 1601-1622.

Thomas, H., Bozec, Y., Elkalay, K., de Baar, H.J.W., 2004. Enhanced open ocean storage of $\mathrm{CO}_{2}$ from shelf sea pumping. Science 304, 1005-1008.

Thomas, H., Bozec, Y., Elkalay, K., de Baar, H.J.W., Borges, A.V., Schiettecatte, L.-S., 2005a. Controls of the surface water partial pressure of $\mathrm{CO}_{2}$ in the North Sea. Biogeosciences 2, 323-334.

Thomas, H., Bozec, Y., de Baar, H.J.W., Elkalay, K., Frankignoulle, M., Schiettecatte, L.S., Kattner, G., Borges, A.V., 2005b. The carbon budget of the North Sea. Biogeosciences 2, 87-96.

Tsunogai, S., Watanabe, S., Sato, T., 1999. Is there a "continental shelf pump" for the absorption of atmospheric $\mathrm{CO}_{2}$ ? Tellus. Series B, Chemical and Physical Meteorology 51 (3), 701-712.

Van bennekom, A.J., Wetsteijn, F.J., 1990. The winter distribution of nutrients in the Southern Bight of the North Sea (1961-1978) and in the estuaries of the Scheldt and the Rhine/Meuse. Netherlands Journal of Sea Research 25, 75-87.

van Der Zee, C., Chou, L., 2005. Seasonal cycling of phosphorus in the Southern Bight of the North Sea. Biogeosciences 2, 27-42.

Wanninkhof, R.H., 1992. Relationship between wind speed and gas exchange over the ocean. Journal of Geophysical Research 97 (C5), 7373-7382.

Wanninkhof, R., McGillis, W.R., 1999. A cubic relationship between air-sea $\mathrm{CO}_{2}$ exchange and wind speed. Geophysical Research Letters 26, 1889-1892.

Weiss, R.F., 1974. Carbon dioxide in water and seawater: the solubility of a non-ideal gas. Marine Chemistry 2, 203-215. 